\title{
Elucidation of Abnormal Potential Responses of Cation-Selective Electrodes with Solid-State Membranes to Aqueous Solutions of $\mathrm{CuCl}_{2}$ and $\mathrm{CdI}_{2}$
}

\author{
Yoshihiro Kudo $^{1 *}$, Daisuke Todoroki ${ }^{2}$, Nobukazu Suzuki ${ }^{2}$, Naoki Horiuchi ${ }^{1}$, \\ Shoichi Katsuta ${ }^{1}$, Yasuyuki Takeda ${ }^{1}$ \\ ${ }^{1}$ Graduate School of Science, Chiba University, Chiba, Japan \\ ${ }^{2}$ Department of Chemistry, Faculty of Science, Chiba University, Chiba, Japan \\ E-mail: iakudo@faculty.chiba-u.jp \\ Received September 9, 2010; revised January 5, 2011; accepted January 10, 2011
}

\begin{abstract}
An empirical solution to abnormal potential responses, showing peaks of emf, of commercial $\mathrm{Cu}^{2+}-$ and $\mathrm{Cd}^{2+}$-selective electrodes with solid-state membranes was proposed for aqueous solutions of $\mathrm{CuCl}_{2}$ and $\mathrm{CdI}_{2}$. The two-step processes of $\mathrm{M}^{n+}+\mathrm{Y}^{n-}$ (s: solid phase $) \rightleftharpoons \mathrm{MY}(\mathrm{s})$ and $\mathrm{MY}(\mathrm{s})+2 \mathrm{X}^{-} \rightleftharpoons \mathrm{X}_{2} \mathrm{MY}^{2-}(\mathrm{s})(n=1$, 2 ) at a test solution/electrode-interface were considered as a model. Here, $\mathrm{M}^{n+}, \mathrm{Y}^{n-}$, and $\mathrm{X}^{-}$refer to a divalent or univalent cation, functional groups of electrode materials, and a halide ion $\left(\mathrm{X}^{-}=\mathrm{Cl}^{-}, \mathrm{Br}^{-}, \mathrm{I}^{-}\right)$, respectively. By applying electrochemical potentials to these processes at $n=2$, we derived an equation. Regression analyses based on the equation reproduced well the plots of emf versus $\log 2\left({ }^{*}[\mathrm{M}]_{\mathrm{t}}\right)$ for the $\mathrm{Cd}(\mathrm{II})$ and $\mathrm{Cu}(\mathrm{II})$ systems: $*[\mathrm{M}]_{\mathrm{t}}$ denotes a total concentration of species relevant to $\mathrm{M}^{2+}$ in a bulk of the aqueous solution. Also, as an apparent selectivity coefficient $\left(K_{\mathrm{s}}\right)$ we obtained $\log K_{\mathrm{s}}\left(\mathrm{CdBr}_{2}\right)=4.28 \pm 0.22, \log K_{\mathrm{s}}\left(\mathrm{CdI}_{2}\right)=6.98$ $\pm 0.05, \log K_{\mathrm{s}}\left(\mathrm{CuCl}_{2}\right)=3.96 \pm 0.09$, and $\log K_{\mathrm{s}}\left(\mathrm{CuBr}_{2}\right)=11.4$ at $25^{\circ} \mathrm{C}$. The magnitude in $-\log K_{\mathrm{s}}$ reflected that in the logarithmic solubility product, $\log \left\{*\left[\mathrm{M}^{2+}\right]\left(*\left[\mathrm{X}^{-}\right]\right)^{2}\right\}$, for bulk water, where ${ }^{*}\left[\mathrm{M}^{2+}\right]$ or $*\left[\mathrm{X}^{-}\right]$denotes a molar concentration of the bulk solution of $\mathrm{M}^{2+}$ or $\mathrm{X}^{-}$at equilibrium, respectively. Moreover, a mixture of $\mathrm{CuSO}_{4}$ with $\mathrm{NaCl}$ at the molar ratio of 1:1 yielded a plot similar to that of $\mathrm{CuCl}_{2}$.
\end{abstract}

Keywords: Cation-Selective Electrode, Solid-State Membranes, Potential Response, Solubility Product, Potentiometry

\section{Introduction}

Many ion-pair (or complex) formation constants of divalent metal salts $\left(\mathrm{MX}_{2}\right)$ in water $(\mathrm{w})$ have been determined so far [1-4]. In the course of potentiometric determination of these constants for $\mathrm{CdI}_{2}$ and $\mathrm{CdBr}_{2}$ in a bulk w by using a commercial $\mathrm{Cd}^{2+}$ electrode with a solid-state membrane [4], plots of the emf versus $\log 2\left(*\left[\mathrm{CdX}_{2}\right]_{\mathrm{t}}\right)$ gave peaks, where $*\left[\mathrm{CdX}_{2}\right]_{\mathrm{t}}\left(=*[\mathrm{Cd}]_{\mathrm{t}}\right)$ denotes a total concentration of $\mathrm{CdX}_{2}$ in the bulk w. Especially, as shown in Figure 1 of the previous paper [4], a slope of the plot for the $\mathrm{CdI}_{2}$ system was positive in the lower range of $\log 2\left(*\left[\mathrm{CdI}_{2}\right]_{\mathrm{t}}\right)$, while it was negative in its higher range. As a result, the $\mathrm{Cd}^{2+}$ electrode could not be used for the determination of the formation constants. Such plots with the peaks, namely $\Lambda$-shaped plots, have been reported in the cases of potential responses of cation-selective electrodes with liquid membranes to some anions, such as $\mathrm{F}^{-}, \mathrm{SCN}^{-}$and $\mathrm{ClO}_{4}^{-}$[5-7]. Also, similar potential responses were observed in the case of a commercial $\mathrm{Cu}^{2+}$ electrode with a solid-state membrane, when the ion-pair formation of $\mathrm{CuCl}_{2}$ in $\mathrm{w}$ had been studied for the application to solvent-extraction experiments of some $\mathrm{Cu}(\mathrm{II})$ salts by crown compounds into 1,2-dichloroethane. The same application has been reported for Cd(II) salts [8].

However, it is difficult to see some models proposed for elucidating the potential responses of the electrodes with the liquid membranes [5,7-12] and its elucidation seems to be unclear [5,7]. The Nicolsky- or NicolskyEisenman-type equation $[9,13]$ does not reproduce the $\Lambda$-shaped potential responses. Also, some equations de- 
rived from the inverted-Nernstian response model based on the complexation of ionophores with primary and/or secondary ions $[11,12]$ can not clearly express the responses.

In the present paper, we tried the reproduction of the above plots by introducing a model with two-step processes around the electrode/solution interface, in addition to ion-pair formation. Applying an electrochemical potential to these processes, we derived an equation and thereby reproduced the $\Lambda$-shaped plot of the $\mathrm{CdI}_{2}$ system. Also, plots similar to that of the $\mathrm{CdX}_{2}$ system $(\mathrm{X}=\mathrm{Cl}$ to I) were observed in $\mathrm{CuX}_{2}(\mathrm{Cl}, \mathrm{Br})$ and $\mathrm{CaX}_{2}$ systems $(\mathrm{Cl}$ to I). Furthermore, properties of commercial ISEs, $\mathrm{Cd}^{2+}$ and $\mathrm{Cu}^{2+}$ electrodes with solid-state membranes and $\mathrm{Ca}^{2+}$ one with a liquid membrane, were examined using an apparent selectivity coefficient $\left(K_{\mathrm{s}}\right)$ obtained at $25^{\circ} \mathrm{C}$ from the analyses of these plots by the derived equation. Additionally, the equation was extended to potential responses of $\mathrm{M}^{+}$-selective electrodes.

\section{Experimental}

\subsection{Chemicals}

Purities of $\mathrm{CuCl}_{2} \cdot 2 \mathrm{H}_{2} \mathrm{O}$ (guaranteed pure, Kanto), $\mathrm{CuBr}_{2}$ (guaranteed pure, Kanto), $\mathrm{CuSO}_{4} \cdot 5 \mathrm{H}_{2} \mathrm{O}$ (guaranteed pure, Wako), $\mathrm{CaBr}_{2}(98 \%$, degree of hydration $\leq 1$, Aldrich), and $\mathrm{CaI}_{2} \cdot n \mathrm{H}_{2} \mathrm{O}(99.5 \%, n=3$ to 4 , Wako) were determined by chelatometric titration with EDTA [4]. $\mathrm{NaCl}$ (99.99\%, Wako) and $\mathrm{KCl}$ ( $\geq 99.8 \%$, Kanto) were prepared from the procedures described in a previous paper [14]. Other chemicals were used without any purification. Tap water was distilled once and then deionized by passing through a Milli-Q Lab System. This water was used for preparing all aqueous solutions.

\subsection{Instruments}

As the commercial ISEs, the $\mathrm{Cu}^{2+}$ electrode (Horiba, type 8006-10C) with the solid-state membrane and the $\mathrm{Ca}^{2+}$ electrode (Horiba, type 8203-10C) with the liquid membrane were employed. The emf values were measured with a Horiba $\mathrm{pH} /$ ion meter F23 equipped with the ISE and a reference electrode (Horiba, type 2565A-10T) [4, $15]$.

\subsection{Emf Measurements}

Emf values were measured at $25 \pm 0.3^{\circ} \mathrm{C}$ in the following cell: $\mathrm{Ag}|\mathrm{AgCl}| 0.1 \mathrm{~mol} \cdot \mathrm{L}^{-1} \mathrm{KCl}$ or $\mathrm{NaCl} \mid 1 \mathrm{~mol} \cdot \mathrm{L}^{-1}$ $\mathrm{KNO}_{3} \mid$ test solution|ISE [4]. As the test solutions, aqueous solutions of $\mathrm{CuCl}_{2}, \mathrm{CuBr}_{2}, \mathrm{CaBr}_{2}, \mathrm{CaI}_{2}, \mathrm{NaCl}$, and mixtures of $\mathrm{CuSO}_{4}$ with $\mathrm{NaCl}$ were used. As a result of computation by the Henderson equation, the liquid junction potentials $(<3 \mathrm{mV})$ at the $1 \mathrm{~mol} \cdot \mathrm{L}^{-1} \mathrm{KNO}_{3} \mid$ test solution-interface were neglected [4]: this shows that the aqueous solution of $1 \mathrm{~mol} \cdot \mathrm{L}^{-1} \mathrm{KNO}_{3}$ adequately functions as a salt bridge. The mixtures were prepared by mixing $0.5006 \mathrm{~mol} \cdot \mathrm{L}^{-1}$ of $\mathrm{CuSO}_{4}$ with $0.5007 \mathrm{~mol} \cdot \mathrm{L}^{-1}$ of $\mathrm{NaCl}$ at given volume-ratios.

\section{Results and Discussion}

\subsection{Log *[X]t-Dependence of Emf}

Figure 1 shows the dependence of the experimental emfvalues on the $\log *[\mathrm{X}]_{\mathrm{t}}$ ones for (a) the $\mathrm{CuX}_{2}(\mathrm{X}=\mathrm{Cl}$, $\mathrm{Br}$ ), (b) $\mathrm{CdX}_{2}$, and $\mathrm{CaX}_{2}(\mathrm{Br}, \mathrm{I})$ systems. Here, $*[\mathrm{X}]_{\mathrm{t}}$ denotes a total concentration of species relevant to $\mathrm{X}^{-}$in the bulk $\mathrm{w}$ and equals $2\left(*\left[\mathrm{MX}_{2}\right]_{\mathrm{t}}\right)$. Therefore, this relation indicates that the plots of emf versus $\log *[\mathrm{X}]_{\mathrm{t}}$ are actually equivalent with those versus $\log \left\{2\left(*\left[\mathrm{MX}_{2}\right]_{\mathrm{t}}\right)\right\}$ in Figures 1 and 2 ssee Equations (10) \& (10a)\} and accordingly the plots become showed the $\log \left(*\left[\mathrm{MX}_{2}\right]_{\mathrm{t}}\right)-$ dependence of emf with a constant deviation of $\log 2$. Except for the $\mathrm{CuBr}_{2}$ system, these plots had positive slopes of 26 to $37 \mathrm{mV} /$ decade in the lower $\log *[\mathrm{X}]_{\mathrm{t}}$ ranges, showing the Nernstian responses of the electrodes, and then became the lower or negative slopes in the higher ranges. Only the negative slope was observed for the $\mathrm{CuBr}_{2}$ system (open diamond in Figure 1(a)) under the present experimental conditions. Its value shows that the $\mathrm{Cu}^{2+}$ electrode used can act as a selective electrode for $\mathrm{Br}^{-}$, as suggested on its instruction manual. Also, the fact means that, even in the lower $\log *[\mathrm{X}]_{\mathrm{t}}$ range, its solid-state membrane more-preferentially interacts with $\mathrm{Br}^{-}$than does with $\mathrm{Cu}^{2+}$.

Peaks in emf seemed to shift into the higher values of $\log *[\mathrm{X}]_{\mathrm{t}}$ in the order $\mathrm{X}=\mathrm{I}<\mathrm{Br}<\mathrm{Cl}$ for the $\mathrm{MX}_{2}$ systems employed (Figure 1). In going from $\mathrm{X}=\mathrm{Br}$ to $\mathrm{I}$, their peaks were well-defined for the $\mathrm{Cd}(\mathrm{II})$ system (Figure 1(b)), while, in going from $\mathrm{Cl}$ to $\mathrm{Br}$, those was less-defined for the $\mathrm{Cu}$ (II) system (Figure 1(a)).

\subsection{Contribution of Ion-Pair Formation to the Plots of Emf versus Log * $[\mathrm{X}]_{\mathrm{t}}$}

Only the Nernstian slopes of about $30 \mathrm{mV} /$ decade have been observed in calibration curves for the aqueous solutions of $\mathrm{Cd}\left(\mathrm{NO}_{3}\right)_{2}$ with $0.1 \mathrm{~mol} \cdot \mathrm{L}^{-1} \mathrm{KNO}_{3}$ (as an adjuster of ionic strength, $I$ ), $\mathrm{CuSO}_{4}$ with $0.1 \mathrm{~mol} \cdot \mathrm{L}^{-1} \mathrm{KNO}_{3}$, and $\mathrm{CaCl}_{2}$ with $0.1 \mathrm{~mol} \cdot \mathrm{L}^{-1} \mathrm{KCl}$, as shown in the figures of their instruction manuals. These facts indicate that the ion-pair (or complex) formation for these salts at $I=0.1$ mol. $\mathrm{L}^{-1}$ with $\mathrm{KX}\left(\mathrm{X}^{-}=\mathrm{NO}_{3}^{-}, \mathrm{Cl}^{-}\right)$does not practically 


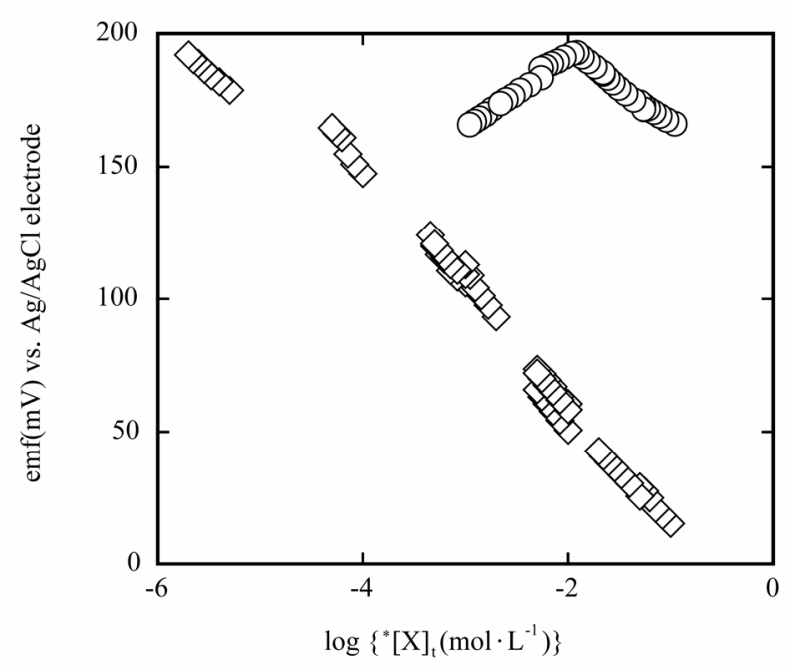

(a)

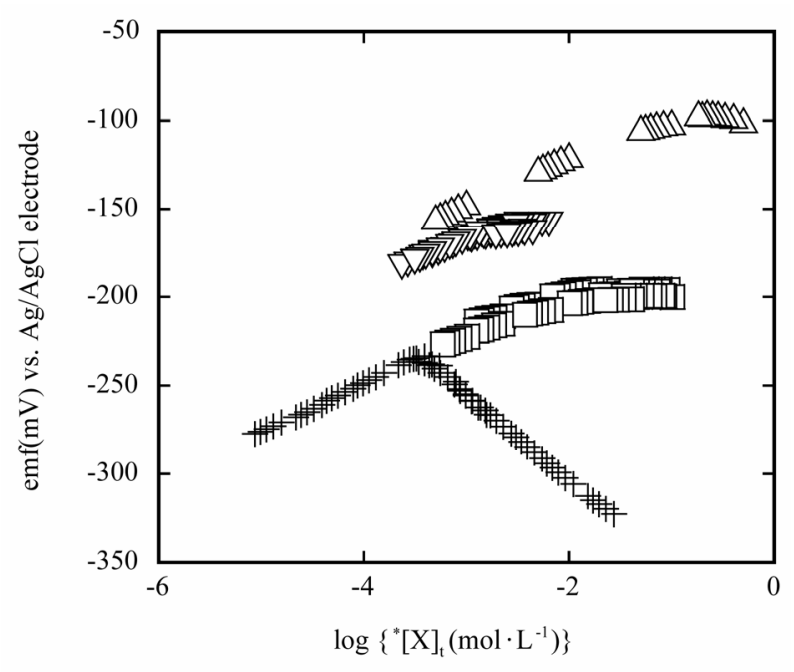

(b)

Figure 1. Plots of emf versus $\log { }^{*}[\mathrm{X}]_{\mathrm{t}}$ for the $\mathrm{CuX}_{2}(\mathrm{X}=\mathrm{Cl}$ : $\circ$; Br: $\diamond), \mathrm{CdX}_{2}\{\mathrm{Br}: \square$; I: $+[4]\}$, and $\mathrm{CaX}_{2}$ systems (Br: $\Delta$; I: $\nabla)$.

influence the linearity of the calibration curves. For example, the calibration curve for the aqueous solution of $\mathrm{CuSO}_{4}$ is expressed as emf $=a+b \log *\left[\mathrm{Cu}^{2+}\right]=a+b$ $\log \left[*[\mathrm{Cu}]_{\mathrm{t}} /\left\{1+K_{\mathrm{CuSO} 4}\left(*\left[\mathrm{SO}_{4}^{2-}\right]\right)\right\}\right] \approx a^{\prime}+b \log *[\mathrm{Cu}]_{\mathrm{t}}$, being the experimental equation of the calibration curve, where $K_{\mathrm{CuSO} 4}=*\left[\mathrm{CuSO}_{4}\right] /\left(*\left[\mathrm{Cu}^{2+}\right]\right) *\left[\mathrm{SO}_{4}^{2-}\right](\leq 251$ $\left.\mathrm{mol} \cdot \mathrm{L}^{-1}[16]\right), *[\mathrm{Cu}]_{\mathrm{t}}=*\left[\mathrm{Cu}^{2+}\right]+*\left[\mathrm{CuSO}_{4}\right]$, and $a^{\prime} \equiv a-$ $b \log \left\{1+K_{\mathrm{CuSO} 4}\left(*\left[\mathrm{SO}_{4}^{2-}\right]\right)\right\}$. The symbol $*\left[\mathrm{Cu}^{2+}\right]$ or $*\left[\mathrm{CuSO}_{4}\right]$ refers to a molar concentration of $\mathrm{Cu}^{2+}$ or $\mathrm{CuSO}_{4}$ in the bulk $\mathrm{w}$ at equilibrium, respectively. This relation of emf to $\log *[\mathrm{Cu}]_{\mathrm{t}}$ suggests that, in spite of the larger $K_{\mathrm{CuSO} 4}$ value, the condition of either $1>K_{\mathrm{CuSO} 4}$ $\left(*\left[\mathrm{SO}_{4}^{2-}\right]\right)$ or $1+K_{\mathrm{CuSO} 4}\left(*\left[\mathrm{SO}_{4}^{2-}\right]\right) \approx$ constant holds actually. In other words, the condition indicates that the

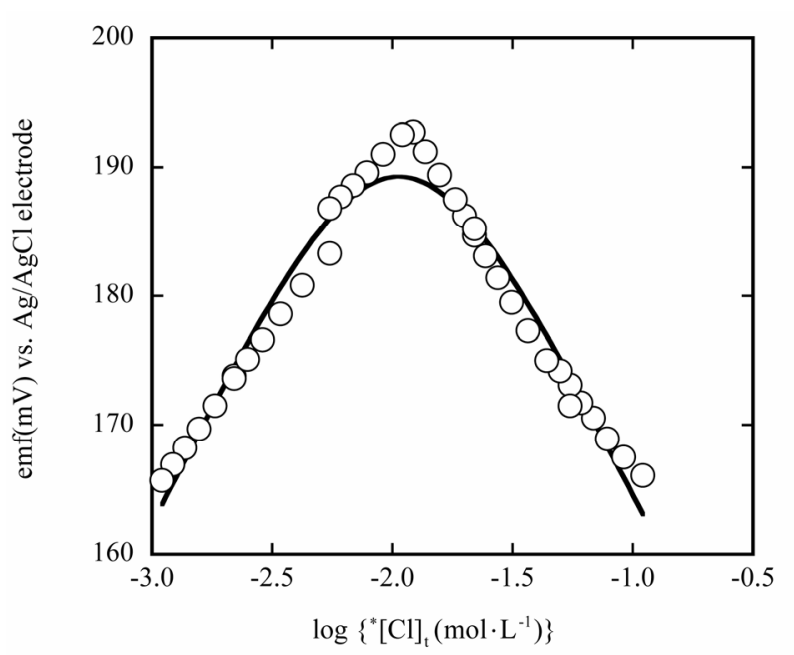

Figure 2. Plots of emf versus $\log *[\mathrm{CI}]_{\mathrm{t}}$ for the $\mathrm{CuCl}_{2}$ system.

ion-pair formation is less effective for the $b$ (slope) value of the calibration curve, while it is somewhat effective for the $a$ (intercept) value. Also, it is predicted that its effects on the $\mathrm{Cd}\left(\mathrm{NO}_{3}\right)_{2}$ and $\mathrm{CaCl}_{2}\left(K_{\mathrm{CaCl}} \leq 41 \mathrm{~mol} \cdot \mathrm{L}^{-1}\right.$ at $\left.25^{\circ} \mathrm{C}[4,15]\right)$ solutions are lower than that on the $\mathrm{CuSO}_{4}$ solution. In comparison with the $\mathrm{KCuSO}_{4}$ value(s) [16], the above condition should hold for the $\mathrm{CdI}_{2}$ system with $K_{\mathrm{CdI}} \leq 308 \mathrm{~mol} \cdot \mathrm{L}^{-1}$ at $25^{\circ} \mathrm{C}[4]: \mathrm{emf}=a+b \log *\left[\mathrm{Cd}^{2+}\right] \approx$ $a+b \log \left[*[\mathrm{Cd}]_{\mathrm{t}} /\left\{1+K_{\mathrm{CdI}}\left(*\left[\mathrm{I}^{-}\right]\right)\right\}\right] \approx a^{\prime}+b \log *[\mathrm{Cd}]_{\mathrm{t}}$ in the $\log *[\mathrm{Cd}]_{\mathrm{t}}$ range of -5 to -2 at least $[4]$, where $*[\mathrm{Cd}]_{\mathrm{t}}$ $\approx *\left[\mathrm{Cd}^{2+}\right]+*\left[\mathrm{CdI}^{+}\right]=*\left[\mathrm{Cd}^{2+}\right]+K_{\mathrm{CdI}}\left(*\left[\mathrm{Cd}^{2+}\right]\right) *\left[\mathrm{I}^{-}\right]$. These results indicate that the condition of $1 \gg K_{\mathrm{MX}}\left(*\left[\mathrm{X}^{-}\right]\right)$ holds for the present $\mathrm{M}^{\mathrm{II}} \mathrm{X}_{n}(n=1,2)$ systems. The same discussion should be true of $*[\mathrm{X}]_{\mathrm{t}}$ because of $*[\mathrm{X}]_{\mathrm{t}}=$ $2\left(*[\mathrm{M}]_{\mathrm{t}}\right)$. The above results may be similar to that clarified by Kakiuchi: when the volume ratio of the membrane to the test solution approaches zero, the potential generated at its interface does not affected by the ion-pair formation in the membrane [17].

\subsection{Semi-Theoretical Treatment for Potential Response of $\mathrm{M}^{2+}$-Selective Electrodes to $\mathrm{X}^{-}$}

We considered here the following three processes around the test solution/ISE-interface for the electrode response, neglecting the formation of $\mathrm{MX}_{2}$.

$$
\begin{gathered}
\mathrm{M}^{2+}+\mathrm{Y}^{2-}(\mathrm{s} \text { : solid phase }) \rightleftharpoons \mathrm{MY}(\mathrm{s}) \\
\mathrm{MY}(\mathrm{s})+2 \mathrm{X}^{-} \rightleftharpoons \mathrm{X}_{2} \mathrm{MY}^{2-}(\mathrm{s}) \\
\mathrm{M}^{2+}+\mathrm{X}^{-} \rightleftharpoons \mathrm{MX}^{+}
\end{gathered}
$$

Here, taking the easy formation of four-coordinated $\mathrm{Cu}$ (II) and $\mathrm{Cd}(\mathrm{II})$ complexes with $\mathrm{X}^{-}$into account, we neglected the formation of $\mathrm{XMY}^{-}$species in Equation (2). 
For the overall process of the electrode processes (1) and (2), therefore, the corresponding equilibrium-constant was defined as

$$
\begin{aligned}
K & =\left[\mathrm{X}_{2} \mathrm{MY}^{2-}\right]_{\mathrm{s}} /\left(\left[\mathrm{M}^{2+}\right]\left[\mathrm{Y}^{2-}\right]_{\mathrm{s}}\left[\mathrm{X}^{-}\right]^{2}\right) \\
& =\left(\left[\mathrm{X}_{2} \mathrm{MY}^{2-}\right]_{\mathrm{s}} /\left[\mathrm{Y}^{2-}\right]_{\mathrm{s}}\right) /\left[\mathrm{M}^{2+}\right]\left[\mathrm{X}^{-}\right]^{2}
\end{aligned}
$$

and those for the process (1) to (3) were

$$
\begin{gathered}
K_{1}=[\mathrm{MY}]_{\mathrm{s}} /\left[\mathrm{M}^{2+}\right]\left[\mathrm{Y}^{2-}\right]_{\mathrm{s}}, \\
K_{2}=\left[\mathrm{X}_{2} \mathrm{MY}^{2-}\right]_{\mathrm{s}} /[\mathrm{MY}]_{\mathrm{S}}\left[\mathrm{X}^{-}\right]^{2}
\end{gathered}
$$

and

$$
\begin{aligned}
K_{\mathrm{MX}} & =\left[\mathrm{MX}^{+}\right] /\left[\mathrm{M}^{2+}\right]\left[\mathrm{X}^{-}\right] \\
& =*\left[\mathrm{MX}^{+}\right] / *\left[\mathrm{M}^{2+}\right]\left(*\left[\mathrm{X}^{-}\right]\right),
\end{aligned}
$$

where $[j]$ and $*[j]$ refer to molar concentrations of species $j\left(=\mathrm{M}^{2+}, \mathrm{MX}^{+}, \mathrm{X}^{-}\right)$around the electrode interface and $j$ in a bulk of the test solution, respectively. The subscript (or superscript) "s" means the solid phase of the electrode and can be replaced by "o", which means an organic phase, for the liquid membrane ISE. We used here the molar concentrations instead of the activities, because they render the theoretical treatment complicated and also the experimental calibration curves keep linearity in the ranges of $10^{-5}$ (or $10^{-6}$ ) to $10^{-1} \mathrm{~mol} \cdot \mathrm{L}^{-1}$ for $\mathrm{Cu}^{2+}$ in $\mathrm{w}, 10^{-6}$ to $10^{-1} \mathrm{~mol} \cdot \mathrm{L}^{-1}$ for $\mathrm{Cd}^{2+}$, and $2.5 \times$ $10^{-5}$ to 0.25 (or 1 ) $\mathrm{mol} \cdot \mathrm{L}^{-1}$ for $\mathrm{Ca}^{2+}$, as shown in the specifications [18-20] of a Website.

The above electrode processes (1) and (2) at the interface were also expressed by electrochemical potentials $(\bar{\mu})$ as follows.

$$
\begin{gathered}
\bar{\mu}_{\mathrm{M}}+\bar{\mu}_{\mathrm{Y}}^{\mathrm{s}}=\bar{\mu}_{\mathrm{MY}}^{\mathrm{s}} \\
\bar{\mu}_{\mathrm{MY}}^{\mathrm{s}}+2 \bar{\mu}_{\mathrm{X}}=\bar{\mu}_{\mathrm{X} 2 \mathrm{MY}}^{\mathrm{s}}
\end{gathered}
$$

Arranging Equations (1b) and (2b) by the properties of $\bar{\mu} \quad$ [21], we have easily

$$
\begin{aligned}
\phi_{\mathrm{Y}}^{\mathrm{s}}-\phi_{\mathrm{M}} & =\frac{\mu_{\mathrm{Y}}^{0 \mathrm{~s}}+\mu_{\mathrm{M}}^{0}-\mu_{\mathrm{MY}}^{0 \mathrm{~s}}}{2 F}+\frac{R T}{2 F} \ln \left[\mathrm{M}^{2+}\right] \\
= & \Delta \phi_{\mathrm{Y} / \mathrm{M}}^{0}+\frac{R T}{2 F} \ln \left[\mathrm{M}^{2+}\right] \\
\phi_{\mathrm{X} 2 \mathrm{MY}}^{\mathrm{s}}-\phi_{\mathrm{X}} & =\frac{\mu_{\mathrm{X} 2 \mathrm{MY}}^{0 \mathrm{~s}}-2 \mu_{\mathrm{X}}^{0}-\mu_{\mathrm{MY}}^{0 \mathrm{~s}}}{2 F}+\frac{R T}{2 F} \ln K_{2} \\
& =\Delta \phi_{\mathrm{X} 2 \mathrm{MY} / \mathrm{X}}^{0}+\frac{R T}{2 F} \ln K_{2} .
\end{aligned}
$$

Here, $\phi_{j}, \Delta \phi_{j / j^{\prime}}^{0}$, and $\mu_{j}^{0}$ denote an inner potential for the species $j\left(=\mathrm{M}^{2+}, \mathrm{Y}^{2-}, \mathrm{X}_{2} \mathrm{MY}^{2-}\right)$ in each phase, a standard electrode potential, and a standard chemical potential corresponding to $j$, respectively. $R, T$ and $F$ have the usual meanings. By the sum of Equations (5a) and (6a), we could express the emf value in question as

$$
\mathrm{emf} \approx \Delta \phi_{\mathrm{Y} / \mathrm{M}}^{0}+\frac{R T}{2 F} \ln \left[\mathrm{M}^{2+}\right]+\Delta \phi_{\mathrm{X} 2 \mathrm{MY} / \mathrm{X}}^{0}+\frac{R T}{2 F} \ln K_{2} .
$$

Also, the following relations were derived from mass balance equations around the test solution/electrodeinterface.

$$
\begin{aligned}
{[\mathrm{M}]_{\mathrm{t}} } & =\left[\mathrm{M}^{2+}\right]+\left[\mathrm{MX}^{+}\right]+[\mathrm{MY}]_{\mathrm{s}}+\left[\mathrm{X}_{2} \mathrm{MY}^{2-}\right]_{\mathrm{s}} \\
& \approx\left[\mathrm{M}^{2+}\right]+\left[\mathrm{MX}^{+}\right]+\left[\mathrm{X}_{2} \mathrm{MY}^{2-}\right]_{\mathrm{s}} \\
& \approx\left[\mathrm{M}^{2+}\right]\left(1+K\left[\mathrm{Y}^{2-}\right]_{\mathrm{s}}\left[\mathrm{X}^{-}\right]^{2}\right)
\end{aligned}
$$

by assuming that $1>K_{2}\left[\mathrm{X}^{-}\right]^{2}$ and then $1+K\left[\mathrm{Y}^{2-}\right]_{\mathrm{s}}\left[\mathrm{X}^{-}\right]^{2}$ $>K_{\mathrm{MX}}\left[\mathrm{X}^{-}\right]$(see above for $1>K_{\mathrm{MX}}\left[\mathrm{X}^{-}\right]$) and

$$
\begin{aligned}
{[\mathrm{X}]_{\mathrm{t}} } & =\left[\mathrm{X}^{-}\right]+\left[\mathrm{MX}^{+}\right]+2\left[\mathrm{X}_{2} \mathrm{MY}^{2-}\right]_{\mathrm{s}} \\
& =\left[\mathrm{X}^{-}\right]\left(1+K_{\mathrm{MX}}\left[\mathrm{M}^{2+}\right]+2 K\left[\mathrm{Y}^{2-}\right]_{\mathrm{s}}\left[\mathrm{M}^{2+}\right]\left[\mathrm{X}^{-}\right]\right) \\
& =\left[\mathrm{X}^{-}\right] g
\end{aligned}
$$

with $g=1+K_{\mathrm{MX}}\left[\mathrm{M}^{2+}\right]+2 K\left[\mathrm{Y}^{2-}\right]_{\mathrm{s}}\left[\mathrm{M}^{2+}\right]\left[\mathrm{X}^{-}\right]$. Rearranging Equation (8) as

$$
\begin{aligned}
{\left[\mathrm{M}^{2+}\right] } & =\frac{{ }^{*}[\mathrm{M}]_{\mathrm{t}} D_{\mathrm{M}}}{1+K\left[\mathrm{Y}^{2-}\right]_{\mathrm{S}}\left(\left[\mathrm{X}^{-}\right]_{\mathrm{t}} / g\right)^{2}} \\
& =\frac{{ }^{*}[\mathrm{M}]_{\mathrm{t}} D_{\mathrm{M}}}{\left.1+K\left[\mathrm{Y}^{2-}\right]_{\mathrm{s}}\left(D_{\mathrm{X}} / g\right)^{2}\left(\mathrm{X}^{*}\right]_{\mathrm{t}}\right)^{2}}
\end{aligned}
$$

with $D_{\mathrm{M}}=[\mathrm{M}]_{\mathrm{t}} / *[\mathrm{M}]_{\mathrm{t}}\left\{\approx\left(\left[\mathrm{M}^{2+}\right]+\left[\mathrm{MX}^{+}\right]+[\mathrm{MY}]_{\mathrm{s}}+\right.\right.$ $\left.\left.\left[\mathrm{X}_{2} \mathrm{MY}^{2-}\right]_{\mathrm{s}}\right) /\left(*\left[\mathrm{M}^{2+}\right]+*\left[\mathrm{MX}^{+}\right]\right)\right\}$and $D_{\mathrm{X}}=[\mathrm{X}]_{\mathrm{t}} / *[\mathrm{X}]_{\mathrm{t}}\{\approx$ $\left.\left(\left[\mathrm{X}^{-}\right]+\left[\mathrm{MX}^{+}\right]+2\left[\mathrm{X}_{2} \mathrm{MY}^{2-}\right]_{\mathrm{s}}\right) /\left(*\left[\mathrm{X}^{-}\right]+*\left[\mathrm{MX}^{+}\right]\right)\right\}$and then introducing Equation (9) into Equation (7), we have easily

$$
\begin{aligned}
\mathrm{emf} \approx & \Delta \phi_{\mathrm{Y} / \mathrm{M}}^{0}+\Delta \phi_{\mathrm{X} 2 \mathrm{MY} / \mathrm{X}}^{0}+\frac{R T}{2 F} \ln \frac{K_{\mathrm{m}}}{2}+\frac{R T}{2 F} \ln ^{*}[\mathrm{X}]_{\mathrm{t}} \\
& -\frac{R T}{2 F} \ln \left\{1+K_{\mathrm{s}}\left(^{*}[\mathrm{X}]_{\mathrm{t}}\right)^{2}\right\} \\
= & \Delta \phi_{\mathrm{Y} / \mathrm{M}}^{0}+\Delta \phi_{\mathrm{X} 2 \mathrm{MY} / \mathrm{X}}^{0}+\frac{R T}{2 F} \ln K_{\mathrm{m}}+\frac{R T}{2 F} \ln ^{*}[\mathrm{M}]_{\mathrm{t}} \\
& \left.-\frac{R T}{2 F} \ln \left\{1+4 K_{\mathrm{s}}{ }^{*}[\mathrm{M}]_{\mathrm{t}}\right)^{2}\right\}
\end{aligned}
$$

with $D_{\mathrm{M}} K_{2}=K_{\mathrm{m}}, K\left[\mathrm{Y}^{2-}\right]_{\mathrm{s}}\left(D_{\mathrm{X}} / g\right)^{2}\left\{=K\left[\mathrm{Y}^{2-}\right]_{\mathrm{s}}\left(\left[\mathrm{X}^{-}\right] / *[\mathrm{X}]_{\mathrm{t}}\right)^{2}\right.$ $\left.=\left(\left[\mathrm{X}_{2} \mathrm{MY}^{2-}\right]_{\mathrm{s}} /\left[\mathrm{M}^{2+}\right]\right) /\left(*[\mathrm{X}]_{\mathrm{t}}\right)^{2}\right\}=K_{\mathrm{s}}$, and $*[\mathrm{X}]_{\mathrm{t}}=2\left(*[\mathrm{M}]_{\mathrm{t}}\right)$ $\left\{=2\left(*\left[\mathrm{MX}_{2}\right]_{\mathrm{t}}\right)\right\}$. Here, the $D_{\mathrm{M}}$ and $D_{\mathrm{X}}$ values like distribution ratios at the test solution/electrode-interface were assumed to be much smaller than unity and the term 
$D_{\mathrm{X}} / g$ is dimensionless.

Using emf $=A+B \log *[\mathrm{X}]_{\mathrm{t}}+C \log \left\{1+K_{\mathrm{s}}\left(*[\mathrm{X}]_{\mathrm{t}}\right)^{2}\right\}$, we can immediately analyze the plots of emf versus log $*[\mathrm{X}]_{\mathrm{t}}$ by a non-linear regression: the alphabet $A$ to $C$ mean $A=\Delta \phi_{\mathrm{Y} / \mathrm{M}}^{0}+\Delta \phi_{\mathrm{X} 2 \mathrm{MY} / \mathrm{X}}^{0}+(R T / 2 F) \ln \left(K_{\mathrm{m}} / 2\right), B=$ $2.303 R T / 2 F$ for $\log *[\mathrm{X}]_{\mathrm{t}}$, and $C=-2.303 R T / 2 F$ in Equation (10). Considering asymmetry of the plots (see Figures 1(b) and 2), we distinguished here $B$ from $C$ and computed their values together with estimating whether they are positive or negative. In Equation (10), $K_{\mathrm{s}}$ will act as the potentiometric selectivity coefficient $\left(k^{\mathrm{pot}}\right)$, usually-described for a glass electrode [21], of the anion $\mathrm{X}^{-}$against $\mathrm{M}^{2+}$. Namely, like $k^{\text {pot }}$, the larger the $K_{\mathrm{s}}$ value is, the larger the interference of $\mathrm{X}^{-}$to the potential response of the electrode becomes.

According to the instruction manual, it has been described that the $\mathrm{Cu}^{2+}$ concentration detected by the $\mathrm{Cu}^{2+}$ electrode decreases in the presence of $\mathrm{Cl}^{-}, \mathrm{Br}^{-}$, or $\mathrm{I}^{-}$. From Equation (10a), a difference in emf between $2 *[\mathrm{M}]_{\mathrm{t}}$ $\left(=*[\mathrm{X}]_{\mathrm{t}}\right)=0$ and $\mathrm{x}$ is expressed as $\operatorname{emf}(\mathrm{x})-\operatorname{emf}(0)=B$ $\ln \left\{*[\mathrm{Cu}]_{\mathrm{t}}(\mathrm{x}) / *[\mathrm{Cu}]_{\mathrm{t}}(0)\right\}+C \ln \left(1+K_{\mathrm{S}} \mathrm{x}^{2}\right)$. When experimentally $*[\mathrm{Cu}]_{\mathrm{t}}(\mathrm{x}) / *[\mathrm{Cu}]_{\mathrm{t}}(0) \approx 1$, this equation becomes $\operatorname{emf}(\mathrm{x}) \approx \operatorname{emf}(0)+C \ln \left(1+K_{\mathrm{s}} \mathrm{x}^{2}\right)$. Therefore, the relation of $\operatorname{emf}(0) \neq \operatorname{emf}(\mathrm{x})$ is obtained: namely the inequality of $\operatorname{emf}(\mathrm{x})<\operatorname{emf}(0)$ should hold, because $C<0$ and $\ln \left(1+K_{\mathrm{s}} \mathrm{x}^{2}\right)>0$. This fact, $\operatorname{emf}(\mathrm{x})<\operatorname{emf}(0)$, also indicates that, considering the calibration curve of emf $=$ $a^{\prime}+b \log *[\mathrm{Cu}]_{\mathrm{t}}$ with $b>0\left(\right.$ see 3.2), $10^{-\{\operatorname{emf}(0)-\operatorname{emf}(\mathrm{x})\}) / b}=$ $*[\mathrm{Cu}]_{\mathrm{t}}(\mathrm{x}) / *[\mathrm{Cu}]_{\mathrm{t}}(0)<1$ must hold. This result that $*[\mathrm{Cu}]_{\mathrm{t}}(\mathrm{x})$ becomes smaller than $*[\mathrm{Cu}]_{\mathrm{t}}(0)$ is in accord with that described above. Thus, the above description in the manual is well explained in terms of Equation (10a).

An equation similar to Equation (10) was obtained for the $\mathrm{M}^{+} \mathrm{X}^{-}$system:

$$
\mathrm{emf} \approx A+B \log *[\mathrm{M}]_{\mathrm{t}}+C \log \left\{1+K_{\mathrm{s}}\left(*[\mathrm{M}]_{\mathrm{t}}\right)^{2}\right\}
$$

with $A=\Delta \phi_{\mathrm{YM}}^{0}+\Delta \phi_{\mathrm{X} 2 \mathrm{MY} / \mathrm{X}}^{0}+(R T / 2 F) \ln \left(K_{\mathrm{m}} D_{\mathrm{M}}\right), B=$ $2.303 R T / F$, and $C=-2.303 R T / F$, and $K_{\mathrm{s}}=K\left[\mathrm{Y}^{-}\right]_{\mathrm{s}}\left(D_{\mathrm{M}} / g\right)^{2}$. Here, taking account of the processes, $\mathrm{M}^{+}+\mathrm{Y}^{-}(\mathrm{s}) \rightleftharpoons$ $\mathrm{MY}(\mathrm{s})$ and $\mathrm{M}^{+}+\mathrm{X}^{-} \rightleftharpoons \mathrm{MX}^{0}$ instead of Equations (1) and (3), we modified the $\Delta \phi_{\mathrm{Y} / \mathrm{M}}^{0}, D_{\mathrm{M}}$, and $g$ terms.

\subsection{Reproduction of Plots of Emf versus Log $*[\mathbf{X}]_{\mathrm{t}}$}

A curve in Figure 2 shows the semi-theoretical curve for the $\mathrm{CuCl}_{2}$ system obtained from the above treatment. Thus, the plot was reproduced well. The same analyses also yielded results similar to those for other plots. These $A, B, C$, and $\log K_{\mathrm{s}}$ values are summarized in Table 1 .

The curve (Figure 2) was resolved into $\mathrm{emf}_{\mathrm{M}}$ and $\mathrm{emf}_{\mathrm{X}}$, where emf $=\mathrm{emf}_{\mathrm{M}}+\mathrm{emf}_{\mathrm{X}}$, indicating emf $\mathrm{Cu}_{\mathrm{Cu}}=A+$ $B \log *[\mathrm{Cl}]_{\mathrm{t}}$ and $\operatorname{emf}_{\mathrm{Cl}}=C \log \left\{1+K_{\mathrm{s}}\left(*[\mathrm{Cl}]_{\mathrm{t}}\right)^{2}\right\}$ with $\mathrm{M}=$
$\mathrm{Cu}$ and $\mathrm{X}=\mathrm{Cl}$, from Equation (10). Their emf values are listed in Table 2 with some experimental emf values $\left(\mathrm{emf}{ }^{\text {found }}\right)$. One can see easily the sum of the two emf values, $\mathrm{emf}_{\mathrm{Cu}}$ and $\mathrm{emf}_{\mathrm{Cl}}$, well reproduces the emf ${ }^{\text {found }}$ values within error of about $|2| \mathrm{mV}$. Additionally, Table 2 shows that the $\mathrm{emf}_{\mathrm{Cl}}$ values depress the Nernstian response of the $\mathrm{Cu}^{2+}$ electrode in the $\log *[\mathrm{Cl}]_{\mathrm{t}}$ range more than -2 . Other experimental plots of the emf versus $\log *[\mathrm{X}]_{\mathrm{t}}$ were resolved similarly, except for the $\mathrm{CuBr}_{2}$ system. As Figure 1(a) shows, the Nernstian response for $\mathrm{Cu}^{2+}$ in the presence of $\mathrm{Br}^{-}$in $\mathrm{w}$ was not observed at all. Hence, its plot was analyzed by using the following linear equation: $\mathrm{emf} \approx \mathrm{emf}_{\mathrm{Br}}=A+C \log K_{\mathrm{s}}+(B+$ $2 C) \log *[\mathrm{Br}]_{\mathrm{t}}=A^{\prime}+C^{\prime} \log *[\mathrm{Br}]_{\mathrm{t}}$ under the condition of $K_{\mathrm{s}} \gg\left(*[\mathrm{Br}]_{\mathrm{t}}\right)^{-2}\left(\approx 10^{11.4} \mathrm{~mol}^{-2} \cdot \mathrm{L}^{2}\right.$ at the experimental minimum $\left.*[\mathrm{Br}]_{\mathrm{t}}\right)$, namely $1 \ll K_{\mathrm{s}}\left({ }^{*}[\mathrm{Br}]_{\mathrm{t}}\right)^{2}$ in Equation (10).

The same regression analyses were performed by using Equation (10) for the potential response of the $\mathrm{Ca}^{2+}$ electrode with the liquid membrane. The thus-obtained results are listed in Table 1. The values obtained seem to be comparable with those for the solid-state electrodes.

\subsection{Addition of $\mathrm{NaCl}$ into Aqueous Solution of $\mathrm{CuSO}_{4}$}

Figure 3 shows a variation of the emf values for mixtures of aqueous solutions of $\mathrm{CuSO}_{4}$ with those of $\mathrm{NaCl}$ at $*[\mathrm{NaCl}]_{\mathrm{t}} *\left[\mathrm{CuSO}_{4}\right]_{\mathrm{t}}=1.00$ (open circles) and 3.00 (open squares). Obviously, the emf-versus-log $*\left[\mathrm{CuSO}_{4}\right]_{\mathrm{t}}$ plots were spread out a range of negative slopes with an increase in amount of $\mathrm{NaCl}$. This shows any interferences of $\mathrm{Cl}^{-}$against the potential response of the $\mathrm{Cu}^{2+}$

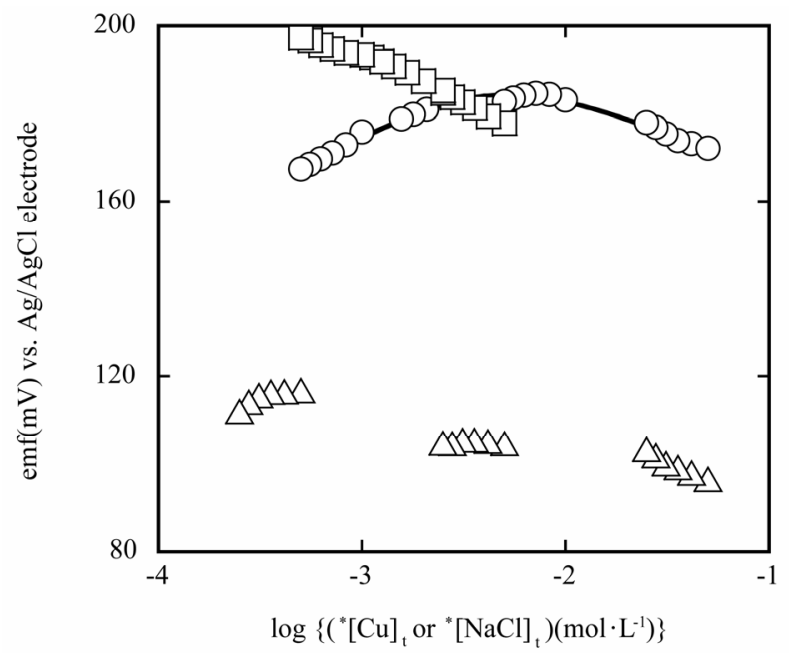

Figure 3. Plots of emf versus $\log *[\mathrm{Cu}]_{t}$ for the mixtures of $\mathrm{CuSO}_{4}$ with $\mathrm{NaCl}$ at $*[\mathrm{NaCl}]_{t} / *\left[\mathrm{CuSO}_{4}\right]_{\mathrm{t}}=1.00(\circ)$ and 3.00 $(\square)$. The plot with open triangles shows a potential response of the $\mathrm{Cu}^{2+}$ electrode to the aqueous solution of $\mathrm{NaCl}$. 
Table 1. Some electrochemical parameters obtained from the plots of emf versus $\log 2\left({ }^{*}\left[\mathrm{MX}_{2}\right]_{\mathrm{t}}\right)$ at $25^{\circ} \mathrm{C}$.

\begin{tabular}{ccccccc}
\hline $\mathrm{MX}_{2}$ & Membrane type & $A(\mathrm{mV})$ & $B(\mathrm{mV} /$ decade $)$ & $C(\mathrm{mV} /$ decade $)$ & $\log K_{\mathrm{s}}$ & $R$ \\
\hline $\mathrm{CdBr}_{2}$ & Solid-state & $-143 \pm 7$ & $26 \pm 2$ & $-13 \pm 1$ & $4.2_{8} \pm 0.2_{2}$ & 0.959 \\
$\mathrm{CdI}_{2}$ & Solid-state & $-104 \pm 7$ & $35 \pm 2$ & $-44 \pm 1$ & $6.98 \pm 0.05$ & 0.994 \\
$\mathrm{CuCl}_{2}$ & Solid-state & $274 \pm 7$ & $37 \pm 3$ & $-37 \pm 1$ & $3.96 \pm 0.09$ & 0.981 \\
$\mathrm{CuBr}_{2}$ & Solid-state & $-19 \pm 3^{\mathrm{a}}$ & $--^{\mathrm{b}}$ & $-40 \pm 1^{\mathrm{a}}$ & $11.4^{\mathrm{c}}$ & 0.987 \\
$\mathrm{CaBr}_{2}$ & Liquid & $-69 \pm 1$ & $26 \pm 1$ & $-16 \pm 2$ & $1.8_{7} \pm 0.1_{9}$ & 0.999 \\
$\mathrm{CaI}_{2}$ & Liquid & $-76 \pm 17$ & $29 \pm 5$ & $-11 \pm 2$ & $6.0_{0} \pm 0.3_{8}$ & 0.976 \\
\hline
\end{tabular}

${ }^{\mathrm{a}}$ Determined by using emf $=A^{\prime}+C^{\prime} \log *[\mathrm{X}]_{\mathrm{t}}{ }^{\mathrm{b}}$ The Nernstian response was not observed. ${ }^{\mathrm{c}}$ Estimated from the condition of $K_{\mathrm{s}} \geq$ $1 /\left(*[\mathrm{Br}]_{\mathrm{t}}\right)^{2}$ at the experimental minimum $*[\mathrm{Br}]_{\mathrm{t}}$.

Table 2. Comparison of calculated emf values ${ }^{\mathrm{a}}$ with the experimental values for the $\mathrm{CuCl}_{2} \mathrm{system}$ at $25^{\circ} \mathrm{C}$.

\begin{tabular}{ccccc}
\hline \multirow{2}{*}{$\log *[\mathrm{Cl}]_{\mathrm{t}}$} & \multicolumn{3}{c}{ Calculated values $(\mathrm{mV})$} & \multirow{2}{*}{ emf $^{\text {found b }}(\mathrm{mV})$} \\
\cline { 2 - 4 } & $\mathrm{emf}_{\mathrm{Cu}}$ & $\mathrm{emf}_{\mathrm{Cl}}$ & $\mathrm{emf}_{\mathrm{Cu}}+\mathrm{emf}_{\mathrm{Cl}}$ & 165.7 \\
\hline-2.959 & 164.5 & -0.2 & 164 & 169.7 \\
-2.804 & 170.3 & -0.4 & 170 & 176.6 \\
-2.539 & 180.1 & -1.2 & 179 & 186.8 \\
-2.260 & 190.4 & -3.9 & 186 & 191.0 \\
-1.699 & 198.6 & -9.1 & 189 & 186.2 \\
-1.503 & 211.1 & -24.7 & 186 & 179.5 \\
-1.214 & 218.4 & -37.0 & 181 & 171.7 \\
\hline
\end{tabular}

${ }^{\mathrm{a}}$ Calculated from the data of $\mathrm{CuCl}_{2}$ in Table 1. ${ }^{\mathrm{b}} \mathrm{Emf} \mathrm{vs} . \mathrm{Ag} / \mathrm{AgCl}$ electrode.

electrode. In addition to the fact, the peak seems to shift into the lower $\log *\left[\mathrm{CuSO}_{4}\right]_{\mathrm{t}}$ values in going from $*[\mathrm{NaCl}]_{\mathrm{t}} / *\left[\mathrm{CuSO}_{4}\right]_{\mathrm{t}}=1$ to 3 . These facts also support the validity of the semi-theoretical treatment described above. Moreover, the $\mathrm{Cu}^{2+}$ electrode did not respond clearly aqueous solutions of $\mathrm{NaCl}$ (see the plot at the open triangles in Figure 3): the $-C$ ' value analyzed by $\mathrm{emf}_{\mathrm{Cl}}$ was less than $8 \mathrm{mV} /$ decade at $R=0.948$. This fact indicates that the presence of only the $\mathrm{Cl}^{-}$ion is not adequate for the potential response of the $\mathrm{Cu}^{2+}$-selective electrode to $\mathrm{Cl}^{-}$, namely, the response of the electrode to $\mathrm{Cl}^{-}$needs the presence of $\mathrm{Cu}^{2+}$ in the test solutions. This result is not inconsistent with the presence of the $\left[\mathrm{Cl}_{2}=\mathrm{Cu}-\mathrm{Y}\right]^{2-}$ unit in the electrode process (2). Since a washing of the electrode with $\mathrm{w}$ resets the electrode potential into an initial condition, it can be supposed that an interaction of $\mathrm{M}^{2+}$ (or $\left.\mathrm{X}_{2} \mathrm{M}\right)$ with $\mathrm{Y}^{2-}(\mathrm{s})$ is weaker than or comparable with that of $\mathrm{M}^{2+}$ with $\mathrm{H}_{2} \mathrm{O}$. The same can be true of the Cd(II) system.

Using Equation (10a), we analyzed the plot at $*\left[\mathrm{NaCl}_{\mathrm{t}} /\right.$ * $\left[\mathrm{CuSO}_{4}\right]_{\mathrm{t}}=1$ in the same manner. The $A, B, C$ and log
$K_{\mathrm{s}}$ values at $R=0.994$ were $247 \pm 5 \mathrm{mV}, 24 \pm 1$ $\mathrm{mV} /$ decade, $-21 \pm 1 \mathrm{mV} /$ decade, and $4.10 \pm 0.09$, respectively (see the curve in Figure 3). The $\log K_{\mathrm{s}}$ value was the same as that for $\mathrm{CuCl}_{2}$ within the experimental errors (see Table 1). Also, a difference in $A$ between the mixture at $*[\mathrm{NaCl}]_{\mathrm{t}} *\left[\mathrm{CuSO}_{4}\right]_{\mathrm{t}}=1$ and the aqueous solution of $\mathrm{CuCl}_{2}$ was $+30 \mathrm{mV}\left(=A^{\mathrm{CuCl2}}-A^{1: 1}\right)$. That is, the difference between the $\log K_{\mathrm{m}}\left(\mathrm{CuCl}_{2}\right)$ and $\log K_{\mathrm{m}}(1: 1)$ values was $1.3_{1}\left[=\log \left\{K_{\mathrm{m}}\left(\mathrm{CuCl}_{2}\right) / K_{\mathrm{m}}(1: 1)\right\} \approx(2 \times\right.$ $0.030 / 0.05916)+\log 2]$, where the $\left(\Delta \phi_{\mathrm{Y} / \mathrm{Cu}}^{0}+\Delta \phi_{\mathrm{Cl} 2 \mathrm{CuY} / \mathrm{Cl}}^{0}\right)$ term was assumed to be constant between the two systems. These facts suggest that the $K_{\mathrm{m}}$ value is dependent on the $*[\mathrm{Cl}]_{\mathrm{t}}$ value, while the $K_{\mathrm{s}}$ value is independent of the present $*[\mathrm{Cl}]_{\mathrm{t}}$ value at least. The strong $*[\mathrm{Cl}]_{\mathrm{t}}$-dependence of $K_{\mathrm{m}}$ can be easily supposed by the reaction (3) with the reaction of $\mathrm{Cl}^{-}$, in other words, an increase in $\left[\mathrm{CuCl}^{+}\right]+\left[\mathrm{Cl}_{2} \mathrm{CuY}^{2-}\right]_{\mathrm{s}}$ in $[\mathrm{Cu}]_{\mathrm{t}}$ and/or $\left[\mathrm{Cl}_{2} \mathrm{CuY}^{2-}\right]_{\mathrm{s}}$ in $K_{2}$, based on the relation $K_{\mathrm{m}}=\left([\mathrm{Cu}]_{\mathrm{t}} / *[\mathrm{Cu}]_{\mathrm{t}}\right) K_{2}$. On the other hand, the $*[\mathrm{Cl}]_{\mathrm{t}}$-dependence of $K_{\mathrm{s}}$ may be depressed by the presence of the $\left(D_{\mathrm{Cl}} / g\right)^{2}$ term in $K_{\mathrm{s}}:\left[\mathrm{Cl}_{2} \mathrm{CuY}^{2-}\right]_{\mathrm{s}} /$ $\left[\mathrm{Cu}^{2+}\right]\left(*[\mathrm{Cl}]_{\mathrm{t}}\right)^{2}=K_{\mathrm{s}}$ \{see the above $K_{\mathrm{s}}$ definition at Equa- 
tions (10) and (10a)\}.

\subsection{Application of the Present Model to Other Liquid Membrane ISEs}

In the same manner as that (see 3.4) for the potential responses measured by the commercial $\mathrm{Ca}^{2+}$ electrode, we analyzed data [5] reported by Morf and Simon for a potential response of the neutral carrier-based $\mathrm{Ca}^{2+}$ electrode with $o$-nitrophenyl octyl ether to an aqueous solution of $\mathrm{Ca}(\mathrm{SCN})_{2}$. The $A, B, C$, and $\log K_{\mathrm{s}}$ values at $R=$ 0.998 were $>(85 \pm 5) \mathrm{mV}, 18 \pm 1 \mathrm{mV} /$ decade, $-22 \pm 2$ $\mathrm{mV} /$ decade, and $4.27 \pm 0.22$, respectively (from Figure 1 in [5]). Also, data [7] reported by Egorov and Lushchik for the potential response of a $\mathrm{H}^{+}$electrode based on a neutral amine-type carrier in dioctyl phthalate-PVC membrane to the hydrofluoric acid solution was analyzed by using Equation (11): $A>(233 \pm 21) \mathrm{mV}, B=74 \pm 7$ $\mathrm{mV} /$ decade, $C=-67 \pm 5 \mathrm{mV} /$ decade, and $\log K_{\mathrm{s}}=4.09 \pm$ 0.19 at $R=0.991$ (from Figure 4 in [7]). The same values were obtained from the analysis with Equation (17) [7] proposed by them: emf $=A+B \log a_{\mathrm{H}^{+}}+(C / 2) \log$ $\left\{2 K_{\mathrm{ex}}\left(a_{\mathrm{H}+}\right)^{2}+\left(K_{\mathrm{ex}}\right)^{2}\left(a_{\mathrm{H}+}\right)^{4}+1\right\}$ under the conditions of $a_{\mathrm{H}+}=a_{\mathrm{F}-}$ and $\bar{C}_{\mathrm{Am}}^{\text {tot }}=\bar{C}_{\mathrm{R}}^{\text {tot }}$ and then this equation is easily arranged into $A+B \log a_{\mathrm{H}^{+}}+C \log \left\{K_{\mathrm{ex}}\left(a_{\mathrm{H}+}\right)^{2}+1\right\}$, being equivalent to Equation (11). Here, $a_{j}\left(j=\mathrm{H}^{+}, \mathrm{F}^{-}\right)$, $\bar{C}_{\mathrm{Am}}^{\text {tot }}$, and $\bar{C}_{\mathrm{R}}^{\text {tot }}$ denote an activity of $j$ in the test solution, total concentrations of amine (Am) and a lipophilic univalent anion $\mathrm{R}^{-}$included in a liquid membrane, respectively. The term $K_{\mathrm{ex}}$ is an extraction constant $\left(\mathrm{mol}^{-2} \cdot \mathrm{L}^{2}\right)$ of $\mathrm{H}^{+} \mathrm{F}^{-}$by Am into the liquid membrane and so corresponds to the $K_{\mathrm{s}}$ value in unit. At least, the results for the two $\mathrm{Ca}^{2+}$ electrodes suggest essential similarity in model between the solid-state membrane ISE and the liquid membrane ISE [7,9]. Also, a model suggesting the formation of $\mathrm{X}_{2} \mathrm{MY}^{2-}$ in a liquid membrane has been proposed [12], where $\mathrm{Y}^{2-}$ means a basic ionophore. However, its detailed description was not found [12]. Furthermore, another model with the formation of $\mathrm{XM}^{\mathrm{I}} \mathrm{Y}^{-}(\mathrm{s})$ in Equation (2) could reproduce the $\Lambda$-shaped plot at $R=0.983$ for the above $\mathrm{H}^{+}$electrode. This $R$ value was smaller than that (0.991) of the model with $\mathrm{X}_{2} \mathrm{M}^{\mathrm{I}} \mathrm{Y}^{2-}(\mathrm{s})$, showing the advantage of the $\mathrm{X}_{2} \mathrm{MY}^{2-}(\mathrm{s})$ formation.

\section{7. $\mathrm{X}^{-}$Concentration at Peak Potential}

The concentration $\left(*[\mathrm{X}]_{\mathrm{t}}^{\text {peak }}\right)$ at the peak potential was estimated from the derivative of Equation (10) under the condition of $\frac{\operatorname{demf}}{d\left({ }^{*}[\mathrm{X}]_{\mathrm{t}}\right)}=0$, where $\frac{\operatorname{demf}}{d\left(^{*}[\mathrm{X}]_{\mathrm{t}}\right)}=\mathrm{B} / *[\mathrm{X}]_{\mathrm{t}}$
$+2 C K_{\mathrm{s}}\left(*[\mathrm{X}]_{\mathrm{t}}\right) /\left\{1+K_{\mathrm{s}}\left(*[\mathrm{X}]_{\mathrm{t}}\right)^{2}\right\}$ and then $*[\mathrm{X}]_{\mathrm{t}}^{\text {peak }}=$ $\sqrt{\frac{-B}{(B+2 C) K_{\mathrm{s}}}}\left\{=2\left(*[\mathrm{M}]_{\mathrm{t}}^{\text {peak }}\right)\right.$ for Equation (10a) $\}$. The $*[\mathrm{X}]_{\mathrm{t}}^{\text {peak }}$ values were $2.6 \times 10^{-4}$ and $0.010 \mathrm{~mol} \mathrm{~L}^{-1}$ for the $\mathrm{CdI}_{2}$ and $\mathrm{CuCl}_{2}$ systems, respectively. These values are in good agreement with those of the peaks shown in Figures 1 and 2. The same result was also obtained for the $\mathrm{Ca}(\mathrm{SCN})_{2}$ system with the experimental log $*[\mathrm{Ca}]_{\mathrm{t}}^{\text {peak }}$ of about $-2.5[5]$. Similarly, the $\log *[\mathrm{HF}]_{\mathrm{t}}^{\text {peak }}$ value (= -2.0) was in good agreement with the experimental upper limit of the proton response [7]. These results indicate well the reproducibility of the plots based on Equations (10) and (11).

\subsection{For Properties of the $\mathrm{M}^{2+}$ Electrodes Employed}

The $K_{\mathrm{s}}$ values were calculated to be $\left\{K_{\mathrm{s}}\left(\mathrm{CdCl}_{2}\right)<\right\}$ $K_{\mathrm{s}}\left(\mathrm{CdBr}_{2}\right)<K_{\mathrm{s}}\left(\mathrm{CdI}_{2}\right)$. This fact indicates that the selectivity of the $\mathrm{Cd}^{2+}$ electrode (Horiba, type 8007-10C with a solid-state membrane) against $\mathrm{X}^{-}$is in the order $\mathrm{X}^{-}=\mathrm{I}^{-}$ $<\mathrm{Br}^{-}<\mathrm{Cl}^{-}$. The same is partly true of the $\mathrm{Cu}^{2+}$ electrode (type 8006-10C): $K_{\mathrm{s}}\left(\mathrm{CuCl}_{2}\right)<K_{\mathrm{s}}\left(\mathrm{CuBr}_{2}\right)$ (Table 1). Predicting $[j]_{\mathrm{s}}\left(j=\mathrm{Y}^{2-}, \mathrm{X}_{2} \mathrm{MY}^{2-}\right)$ to be unity in Equation (4), then the $-\log K_{\mathrm{s}}$ value can be proportional to the logarithmic solubility product, $\log K_{\mathrm{sp}}\left[=\log \left\{*\left[\mathrm{M}^{2+}\right]\right.\right.$ $\left.\left.\left(*\left[\mathrm{X}^{-}\right]\right)^{2}\right\}\right]$. From solubility $(S)$ data $[22]$ at $25^{\circ} \mathrm{C}$ in $\mathrm{w}$, the estimated values were in the orders $\mathrm{CdI}_{2}\left\{\log \left(K_{\mathrm{sp}} / \mathrm{mol}^{3}\right.\right.$ $\left.\left.\mathrm{L}^{-3}\right)=\log 4 S^{3}=0.90_{8}\right\}<\mathrm{CdBr}_{2} \cdot 4 \mathrm{H}_{2} \mathrm{O}\left(1.16_{2}\right)<\mathrm{CdCl}_{2}$. $(5 / 2) \mathrm{H}_{2} \mathrm{O}\left(1.73_{9}\right)$ and $\mathrm{CuBr}_{2}\left(1.79_{5}\right) \leq \mathrm{CuCl}_{2} \cdot 2 \mathrm{H}_{2} \mathrm{O}\left(1.80_{1}\right)$, where it was assumed that $100 \mathrm{~g}$ of aqueous solutions equals $0.10_{0} \mathrm{~L}$ and then the $S$ data in a $\%(w / w)$ unit was converted to that in a mol L${ }^{-1}$ one. This order suggests that the smaller the $\log K_{\mathrm{sp}}\left(\mathrm{MX}_{2}\right)$ value is, the more easy $\mathrm{MX}_{2}$ interacts with the electrode, and then the larger the interference of $\mathrm{X}^{-}$against the electrode becomes. The same discussion can hold for the $\mathrm{CaX}_{2}$ system with the liquid membrane, as follows. The $\log K_{\mathrm{sp}}\left(\mathrm{CaX}_{2}\right)$ values in $\mathrm{w}$ at $25^{\circ} \mathrm{C}$ were estimated to be $1.54_{9}$ for $\mathrm{CaCl}_{2} \cdot 6 \mathrm{H}_{2} \mathrm{O}$, $1.48_{2}$ for $\mathrm{CaBr}_{2} \cdot 6 \mathrm{H}_{2} \mathrm{O}, 1.29_{3}$ for $\mathrm{CaI}_{2} \cdot 6 \mathrm{H}_{2} \mathrm{O}$, and $1.86_{5}$ for $\mathrm{Ca}(\mathrm{NCS})_{2} \cdot 4 \mathrm{H}_{2} \mathrm{O}$ from the $S$ data [22]. The $\log K_{\text {sp }}$ order for $\mathrm{X}=\mathrm{Cl}, \mathrm{Br}$ and $\mathrm{I}$ was in good agreement with the $-\mathrm{log}$ $K_{\mathrm{s}}$ one, although the $\log K_{\mathrm{s}}\left(\mathrm{CaCl}_{2}\right)$ value could not be determined. A deviation of the $\mathrm{Ca}(\mathrm{SCN})_{2}$ system from the order suggests that an incorporation of $\mathrm{Ca}^{2+}$ in complex formation with the neutral carrier (L) around the test solution/liquid membrane-interface strongly contributes an increase in $K_{\mathrm{s}}$, namely a transfer of $\mathrm{CaL}^{2+}, \mathrm{XCaL}^{+}$, $\mathrm{X}_{2} \mathrm{CaL}$ and so on [8] into the o phase.

\section{Conclusion}

It was demonstrated that the present model based on the 
balances among the electrochemical potentials reproduce well the potential responses of the commercial $\mathrm{Cd}^{2+}$ and $\mathrm{Cu}^{2+}$ electrodes with the solid-state membranes in the presence of only the counter halide ions. Also, one could see that the phenomena for the $\mathrm{Ca}^{2+}$ and $\mathrm{H}^{+}$electrodes with the liquid membranes are similarly treated. These facts suggest that the present model contains essential processes being important for the potential responses of electrodes with liquid membranes at least. Further studies will be required for this agreement in potential response between the electrodes with the solid-state membranes and those with the liquid membranes, because the latter electrodes respond under the more-complicated experimental conditions. Not taking account of so-called interfering ions in the test solutions, Equations (10) and (10a) do not reach the general equations derived before. However, Equations (10) and (10a) could directly estimate the parameters, $K_{\mathrm{s}}$ and $A$ (with $K_{\mathrm{m}}$ ). By these equations, one can relate properties of the $\mathrm{M}^{2+}$ and $\mathrm{M}^{+}$electrodes with $K_{\mathrm{sp}}$, although their applications are limited to the solid-state membrane ISEs showing the $\Lambda$-shaped potential responses.

\section{References}

[1] D. N. Hume, D. D. DeFord and G. C. B. Cave, "A Polarographic Study of the Cadmium Thiocyanate Complexes," Journal of American Chemical Society, Vol. 73, 1951, pp. 5323-5325. doi:10.1021/ja01155a094

[2] C. E. Vanderzee and H. J. Dawson Jr., "The Stability Constants of Cadmium Chloride Complexes: Variation with Temperature and Ionic Strength," Journal of American Chemical Society, Vol. 75, 1953, pp. 56595663. doi:10.1021/ja01118a056

[3] P. Gerding, "Thermochemical Studies on Metal Complexes I. Free Energy, Enthalpy, and Entropy Changes for Stepwise Formation of Cadmium(II) Halide Complexes in Aqueous Solution at $25^{\circ} \mathrm{C}$," Acta Chimca Scandinavica, Vol. 20, No. 1, 1966, pp. 79-94. doi:10.3891/acta.chem.scand.20-0079

[4] Y. Kudo, D. Todoroki, N. Horiuchi, S. Katsuta and Y. Takeda, "Ion-Pair Formation of Sodium Salts of Several Oxo Anions and Cadmium Halides in Water and the Distribution of Monovalent Sulfate Ion Pairs in Nitrobenzene," Journal of Chemical and Engineering Data, Vol. 55, No. 7, 2010, pp. 2463-2469. doi:10.1021/je900861h

[5] W. E. Morf and W. Simon, "Cation-Response Mechanism of Neutral Carrier Based Ion-Selective Electrode Membranes," Helvetica Chimica Acta, Vol. 69, 1986, pp. 1120-1131. doi:10.1002/hlca.19860690520

[6] E. Lindner, E. Gráf, Z. Niegreisz, K. Tóth, E. Pungor and R. P. Buck, "Responses of Site-Controlled, Plasticized Membrane Electrodes," Analytical Chemistry, Vol. 60, No. 4, 1988, pp. 295-301. doi:10.1021/ac00155a004
[7] V. V. Egorov and Y. F. Lushchik, " $\mathrm{H}^{+}$-Selective Electrodes Based on Neutral Carriers: Specific Features in Behaviour and Quantitative Description of the Electrode Response," Talanta, Vol. 37, No. 5, 1990, pp. 461-469. doi:10.1016/0039-9140(90)80071-M

[8] Y. Kudo, Y. Kobayashi, S. Katsuta and Y. Takeda, "Ionpair Formation of Cadmium-18-Crown-6 Ethers Complex Ions with Picrate and Chloride Ions in Water and Distribution of Its Picrate Ion-pair Complexes into Benzene," Journal of Molecular Liquids, Vol. 146, 2009, pp. 60-65. doi:10.1016/j.molliq.2009.02.004

[9] T. Kakiuchi and M. Senda, "The Theory of Liquid Ion Exchange Membrane Ion-Selective Electrodes Based on the Concept of the Mixed Ion-Transfer Potential," Bulletin of the Chemical Society of Japan, Vol. 57, No. 7, 1984, pp. 1801-1808. doi:10.1246/bcsj.57.1801

[10] A. Jyo, K. Fukamachi, W. Koga and N. Ishibashi, "The Influence of a Co-ion on the Potential of a Liquid -Exchanger Membrane Electrode," Bulletin of the Chemical Society of Japan, Vol. 50, No. 3, 1977, pp. 670-672. doi:10.1246/bcsj.50.670

[11] P. Bühlmann and Y. Umezawa, "Apparently 'Non-Nernstian' Equilibrium Responses Based on Complexation Between the Primary Ion and a Secondary Ion in the Liquid ISE Membrane," Electroanalysis, Vol. 11, No. 10-11, 1999, pp. 687-693. doi:10.1002/(SICI)1521-4109(199907) $11: 10 / 11<687::$ AID-ELAN687>3.0.CO;2-C

[12] S. Amemiya, P. Bühlmann and K. Odashima, "A Generalized Model for Apparently 'Non-Nernstian' Equilibrium Responses of Ionophore-Based Ion-Selective Electrodes. 1. Independent Complexation of the Ionophore with Primary and Secondary Ions," Analytical Chemistry, Vol. 75, No. 14, 2003, pp. 3329-3339. doi:10.1021/ac026471g

[13] G. D. Christian, "Analytical Chemistry," 5th Edition, John Wiley \& Sons, New York, 1994, p. 335.

[14] Y. Kudo, R. Fujihara, T. Ohtake, S. Katsuta and Y. Takeda, "Evaluation of the Hydrophilic Property of Sodium Ion-Pair Complexes with 3m-Crown- $m$ Ethers $(m=5,6)$ and Their Benzo-Derivatives by Solvent Extraction," Analytical Sciences, Vol. 24, 2008, pp. 999-1003. doi:10.2116/analsci.24.999

[15] Y. Kudo, S. Takeuchi, Y. Kobayashi, S. Katsuta and Y. Takeda, "Potentiometric Determination of Ion-Pair Formation Constants for Cadmium, Calcium Salts, and Cadmium-18-Crown-6 Ether Derivative Complexes with a Sulfate Ion in Water," Journal of Chemical and Engineering Data, Vol. 52, No. 5, 2007, pp. 1747-1752. doi:10.1021/je700135j

[16] S. Wasylkiewicz, "Ion Association in Aqueous Solutions of Electrolytes. II. Mathematical Model for Sulphates of Bivalent Metals," Fluid Phase Equilibria, Vol. 57, 1990, pp. 277-296. doi:10.1016/0378-3812(90)85127-V

[17] T. Kakiuchi, "Limiting Behanior in Equilibrium Partitioning of Ionic Components in Liquid-Liquid Two-Phase Systems," Analytical Chemistry, Vol. 68, No. 20, 1996, pp. 3658-3664. doi:10.1021/ac960032y 
[18] Internet Available: http://www.horiba.com/us/en/application/material-property-characterization/water-analysis/water-quality-electrochemistry-instrumentation/electrodes/ionelectrodes/details/copper-ion-electrode-8006-10c-9511/

[19] Internet Available: http://www.horiba.com/us/en/application/material-property-characterization/water-analysis/water-quality-electrochemistry-instrumentation/electrodes/ionelectrodes/details/cadmium-ion-electrode-8007-10c-9515/

[20] Internet Available: http://www.horiba.com/us/en/application/material-property-characterization/water-analysis/wa- ter-quality-electrochemistry-instrumentation/electrodes/ionelectrodes/details/calcium-ion-electrode-8203-10c-9587/

[21] A. J. Bird and L. R. Faulkner, "Electrochemical Methods: Fundamentals and Applications," 2nd Edition, John Wiley \& Sons, New York, 2001, pp. 60-62; 74-81.

[22] K. A. Inaba, S. Takagi, K. Tajima, H. Tohara, K. Nakatsuka, K. Nakanishi, H. Nakayama, T. Makita and M. Muramatsu, "Handbook of Chemistry, Fundamentals II", In: H. Chihara, Ed., 3rd Edition, The Chemical Society of Japan, Maruzen, Tokyo, 1984, pp. II-166; II-177. 